\title{
Gangguan Tidur pada Anak Usia Bawah Tiga Tahun di Lima Kota di Indonesia
}

\author{
${ }^{*}$ Rini Sekartini, **Nuri Purwito Adi
}

Latar belakang. Tidur merupakan salah satu kebutuhan dasar untuk tumbuh kembang optimal bagi seorang anak. Pola tidur dipengaruhi oleh beberapa faktor yaitu faktor internal pada diri anak dan faktor lingkungan fisik. Gangguan tidur dapat menyebabkan masalah perilaku, emosi, menyebabkan mengantuk pada siang hari, dan dapat mempengaruhi konsentrasi belajar serta daya ingat anak.

Tujuan. Mengetahui prevalensi gangguan tidur pada anak usia bawah tiga tahun menggunakan kuesioner BISQ serta hubungan antara faktor sosiodemografi dengan gangguan tidur.

Metoda. Penelitian ini dilakukan terhadap 385 anak usia bawah 3 tahun di 5 kota di Indonesia. Sejak Januari - Juni 2005. Sampel diperoleh secara consecutive sampling. Merupakan studi analitik seksi silang, menggunakan metode wawancara terpimpin dengan kuesioner yang telah diuji coba dan formulir Brief Infant Sleep Questionnaire (BISQ). Definisi gangguan tidur bila ditemukan satu atau lebih kondisi seperti lama tidur malam kurang dari 9 jam, terbangun pada malam hari lebih dari 3 kali dan lama terbangun pada malam hari lebih dari 1 jam. Data diolah dan dianalisis dengan program SPSS 11, uji Chi-Square, Fisher's Exact test dan Mann-Whitney $U$. Hubungan bermakna secara statistik bila ditemukan nilai $\mathrm{p}<0.005$.

Hasil. Prevalensi gangguan tidur ditemukan pada 44,2\% dari 385 subyek terdiri dari 198 anak laki-laki dan 187 anak perempuan. Rata-rata usia anak 12 bulan. Tingkat pendidikan orangtua sebagian besar tingkat pendidikan sedang, dengan $66,5 \%$ masuk dalam katagori tingkat pendapatan rendah. Sebagian besar anak $(43,1 \%)$ tidur pada posisi telentang, tidur bersama orangtua di tempat tidur yang sama (bed sharing) ditemukan pada $73,5 \%$ dan co-sleeping ditemukan pada $18,7 \%$. Dalam cara menidurkan anak 56,1\% tertidur ketika disusui, dan dari uji statistik didapatkan hubungan bermakna antara tertidur ketika disusui dengan gangguan tidur. Ditemukan pula hubungan bermakna antara jumlah waktu tidur siang dan waktu mulai tidur malam dengan gangguan tidur. Sedangkan faktor sosiodemografi tidak berhubungan bermakna dengan gangguan tidur. Meskipun demikian $42,3 \%$ orangtua beranggapan bahwa gangguan tidur pada anak bukan merupakan suatu masalah.

Kesimpulan. Prevalensi gangguan tidur pada anak bawah 3 tahun ditemukan pada $44,2 \%$ kasus yang diteliti dengan rata-rata usia anak 12 bulan. Ditemukan hubungan bermakna secara statistik antara tertidur ketika disusui dan jumlah waktu tidur siang serta waktu mulai tidur malam dengan gangguan tidur. Tidak ditemukan hubungan bermakna secara statistik antara faktor sosiodemografi dan gangguan tidur. Perangkat BISQ dapat merupakan salah satu alat untuk skrining gangguan tidur pada anak. Prevalensi gangguan tidur yang tinggi dan perhatian orangtua yang kurang terhadap masalah ini, perlu dilakukan penyebaran informasi dan penyuluhan kepada orang tua tentang manfaat tidur dan dampak yang ditimbulkan dari gangguan tidur.

Kata kunci: brief infant sleep questionnaire, gangguan tidur. 
S ebagian besar anak mempunyai pola tidur yang normal, tetapi $15-30 \%$ anak mengalami masalah tidur pada periode bayi. ${ }^{1-3}$ Beberapa ahli menyebutkan bahwa masalah tidur pada masa bayi dapat berlanjut pada usia balita dan masa usia sekolah, dan hal tersebut dapat memprediksi terjadinya masalah tidur dan perilaku nantinya. ${ }^{4}$ Gangguan tidur pada anak dapat mempengaruhi perilaku dan emosi anak, menyebabkan mengantuk pada siang hari, dapat mengurangi perhatian anak pada sekolah, mudah lelah, mengurangi aktivitas fisik, anak menjadi iritabel, impulsif, sering mengganggu, dapat mengurangi daya ingat anak, kadang anak menjadi rewel bahkan menyebabkan temper tantrum. ${ }^{5}$ Masalah tersebut perlu mendapat penanganan secara tepat, dan strategi yang paling efektif adalah melakukan promosi tentang cara mencapai tidur yang baik sejak awal kehidupan. Masalah tidur yang sering dijumpai adalah kesulitan untuk memulai tidur, kesulitan untuk jatuh tertidur dan bangun pada malam hari tetapi tidak dapat tidur kembali. Hal tersebut selain mengganggu anak juga menyebabkan masalah bagi orangtuanya. ${ }^{1,6,7}$

Prevalensi gangguan tidur pada anak sekitar 30\%$35 \%$. Di Beijing, China didapatkan prevalensi gangguan tidur pada anak usia 2-6 tahun sebesar $23,5 \%$. Seringkali gangguan tidur pada anak tidak terdeteksi oleh orangtua dan tidak ditangani dengan benar ${ }^{8,9}$ Keluhan yang biasanya disampaikan oleh orangtua antara lain adalah kebiasaan tidur yang tidak teratur, kurangnya atau berlebihannya waktu tidur, terbangun pada malam hari, dan mengantuk pada siang hari. Anak usia dibawah tiga tahun yang mempunyai kesulitan tidur pada malam hari secara teratur dapat menunjukkan gejala kegelisahan seperti perubahan emosi dan tingkah laku. Beberapa kelainan dapat memperlihatkan gangguan yang lebih berat seperti sleep apnea syndrome dan sudden infant death syndrome. . $^{9-12}$

\footnotetext{
Alamat korespondensi:

Dr. Rini Sekartini, Sp.A.

*Divisi Tumbuh Kembang Pediatri Sosial. Departemen Ilmu Kesehatan Anak FKUI-RSCM. Jl. Salemba no. 6, Jakarta 10430.

Telepon: 021-3160622. Fax.021-3913982

Dr. Nuri Purwito Adi

** Departemen Ilmu Kedokteran Komunitas Fakultas Kedokteran

Universitas Indonesia
}

Salah satu perangkat untuk mendeteksi gangguan tidur adalah a brief screening infant sleep questionnaire (BISQ). Kuesioner ini merupakan kuesioner singkat untuk menjaring gangguan tidur pada anak secara dini dan telah diuji cobakan melalui dua studi. Penelitian pertama membandingkan pengukuran BISQ dengan pengukuran sleep diary dan pengukuran sleep actigraphy untuk kelompok klinis dan kelompok control pada anak usia 5-29 bulan. Penelitian kedua berdasarkan survey melalui internet dari 1028 responden yang telah melengkapi BISQ. Pengukuran BISQ berhubungan secara signifikan dengan pengukuran tidur dari sleep diaries dan actigraphy. ${ }^{13}$

Penelitian ini bertujuan untuk mengetahui prevalensi anak bawah tiga tahun yang mengalami gangguan tidur menggunakan BISQ, mengetahui prevelensi orangtua yang menyadari bahwa gangguan tidur pada anak adalah suatu masalah, mengetahui ada tidaknya hubungan antara faktor sosiodemografi dengan gangguan tidur.

\section{Metoda}

Desain penelitian ini merupakan suatu studi analitik seksi silang ${ }^{14}$ yang dilakukan pada anak usia bawah tiga tahun di 5 kota di Indonesia, yaitu Jakarta, Bandung, Batam, Palembang, dan Medan. Subjek penelitian adalah ibu yang memiliki anak usia bawah tiga tahun, dilakukan sejak bulan Januari sampai Juni 2005.

Pengambilan sampel dilakukan dengan cara consecutive sampling. Penelitian ini dilakukan dengan metoda wawancara terpimpin menggunakan kuesioner yang telah diuji coba dan (BISQ). Definisi gangguan tidur, yaitu bila ditemukan satu atau lebih keadaaan seperti, lama tidur malam (mulai pukul 19.00 sampai pukul 07.00) kurang dari 9 jam, terbangun pada malam hari (mulai pukul 22.00 sampai pukul 06.00) lebih dari 3 kali dan lama terbangun lebih dari 1 jam pada malam hari. Variabel yang dihubungkan dengan gangguan tidur yaitu tingkat ekonomi keluaga, pendidikan ibu, tempat anak tidur, posisi tidur, lama tidur siang, lama waktu yang dibutuhkan untuk tertidur dan cara menidurkan anak.

Data diolah dan dianalisis dengan program SPSS 11, uji statistik yang digunakan yaitu uji $c h i-$ square, Fisher's exact test, Mann-Whitney U. 


\section{Hasil Penelitian dan Pembahasan}

Didapatkan 385 ibu dan anak menjadi subjek penelitian, terdiri dari 198 anak laki-laki dan 187 anak perempuan, rata-rata usia anak 12 bulan (usia minimum 3 hari dan maksimum 55 bulan), rata-rata keluarga mempunyai 2 orang anak. Tingkat pendidikan ayah $49,9 \%$ dikelompokkan dalam tingkat pendidikan sedang, demikian pula 53\% ibu. Sebagian besar ayah bekerja di sektor swasta $(45,7 \%)$ dan ibu $58,7 \%$ tidak bekerja. Pendapatan per kapita per bulan $66,5 \%$ dikatagorikan ke dalam tingkat pendapatan rendah, yaitu tidak lebih dari Rp 578.722,50.

Gangguan tidur pada penelitian ini didapatkan pada $44.2 \%$ sampel, sedangkan $55.8 \%$ lainnya normal. ( Tabel 1)

Tabel 1. Sebaran subjek berdasarkan pola tidur

\begin{tabular}{lll}
\hline Pola tidur & Frekuensi & Presentase \\
\hline Normal & 215 & 55.8 \\
Gangguan tidur & 170 & 44.2 \\
\hline Total & 385 & 100 \\
\hline
\end{tabular}

Sebagian besar masalah tidur pada anak disebabkan kurangnya durasi tidur sesuai usia (kurang secara kuantitas) atau gangguan dan fragmentasi dari tidur (kualitas tidur yang buruk). Kurang tidur biasanya disebabkan oleh kesulitan memulai (delayed sleep onset) dan atau kesulitan untuk mempertahankannya (prolonged nights waking), sedangkan kualitas tidur yang buruk sebagian besar disebabkan gangguan yang sering, berulang-ulang, dan bermakna terhadap tidur seseorang. ${ }^{12}$

Posisi yang paling aman untuk mengurangi risiko terjadinya sudden infant death syndrome (SIDS) bagi bayi adalah terlentang.' Selain itu anak seharusnya tidak tidur bersama orangtuanya. Tempat tidur dewasa tdak cocok bagi bayi dan anak. Banyak penelitian menunjukkan dengan tidur satu tempat tidur dengan orangtua (bed sharing) dapat menempatkan bayi dalam risiko terjepit atau tersedak. Jika orangutan ingin bersama bayinya, bayi ditempatkan dalam tempat tidur yang terpisah, tetapi masih dalam satu ruangan (co-sleeping). ${ }^{8}$ Pada penelitian ini didapatkan posisi tidur anak $43,1 \%$ terlentang, 39,5\% miring dan 17,4\% tengkurap. Hal yang berbeda ditemukan pada penelitian Tandradynata J dkk di Jakarta, 45\% anak batita tidur pada posisi miring. ${ }^{15}$

Anak seharusnya tidak tidur bersama orangtuanya di tempat tidur atau kamar yang sama. Banyak studi menunjukkan bahwa dengan tidur satu tempat tidur dengan orangtua (bed sharing) dapat menempatkan anak dalam risiko terjepit atau tersedak. Beberapa negara di wilayah Timur, co-sleeping masih dianggap sesuatu yang boleh dilakukan. ${ }^{8}$ Pada penelitian ini sebagian besar anak tidur bersama orangtua pada tempat tidur yang sama $(73,5 \%)$ dan $18.7 \%$ tidur di kamar orangtua pada tempat tidur terpisah (cosleeping). Hasil yang sama ditemukan pada penelitian Xianchen Liu di Cina bahwa 48\% anak tidur bersama orangtuanya (sharing bed) dan 21,6\% tidur di kamar yang sama dengan orangtua (sharing room / cosleeping). ${ }^{16}$ Berbeda dengan penelitian Avi Sadeh ${ }^{13}$ anak batita yang tidur bersama orangtuanya sebesar $16,7 \%$, demikian pula dengan penelitian Oskar G Jenni dkk, hanya 10 anak yang tidur bersama orangtuanya pada 1 tahun pertama kehidupan. ${ }^{17} \mathrm{Hal}$ tersebut terjadi karena adanya perbedaan kultur dan budaya antara negara Timur dan negara Barat. Lebih lanjut dikatakan bahwa sharing bed atau co-sleeping memberikan kontribusi terhadap lambatnya anak mulai tidur dan terbangun lebih pagi, hal tersebut terjadi karena pola tidur anak akan mengikuti pola tidur orangtuanya. ${ }^{16}$

Pada penelitian ini, secara uji statistik menunjukkan hubungan yang tidak bermakna antara tempat anak tidur dengan gangguan tidur (Chi-Square, $p=0,46)$. Berbeda dengan temuan Avi Sadeh, penelitiannya menemukan hubungan antara tempat anak tidur dengan kriteria gangguan tidur. Anak yang tidur di tempat tidur sendiri dapat tidur malam lebih lama, lebih cepat tertidur, lebih jarang terbangun pada malam hari, dan terbangun pada malam hari lebih singkat dibandingkan dengan anak yang tidur bersama orangtuanya. ${ }^{13}$

Berdasarkan bagaimana cara anak tertidur $56,1 \%$ anak tertidur ketika disusui, 23,1\% anak tertidur di dekat orang tuanya, $22,6 \%$ anak tertidur di gendongan, 22,6\% anak tertidur sendiri di tempat tidur dan 20\% anak tertidur ketika diayun (Tabel 2). Hasil yang sama ditemukan pada penelitian Avi Sadeh bahwa sebagian besar anak $(32,2 \%)$ anak tertidur ketika disusui. ${ }^{13}$ 
Beberapa faktor baik dari anak maupun orangtua dicoba dicari hubungan dengan ada tidaknya gangguan tidur pada anak. Antara tempat anak tidur dan posisi tidur anak, secara uji statistik tidak didapatkan hubungan bermakna dengan gangguan tidur. Terdapat hubungan bermakna secara statistik antara gangguan tidur dengan tertidur ketika disusui (Tabel 3)

Jumlah dan lama tidur siang bervariasi menurut usia bayi dan anak. Semakin besar anak, maka kebutuhan tidur siangnya semakin berkurang. ${ }^{12}$ Pada bayi dan anak yang masih memerlukan tidur siang harus dibiasakan tidur sang dengan jadwal yang teratur. Bila jadwal tidur siang terlewati, sebaiknya anak dipertahankan tetap terjaga hingga periode tidur berikutnya. Hal ini bermanfaat untuk menjaga ritme tidur anak tidak berubah. ${ }^{15} \mathrm{Ke}-$ butuhan tidur siang anak batita berkurang seiring dengan bertambahnya usia anak. ${ }^{10}$ Pada umumnya anak yang tidur siang melebihi kebutuhannya akan tidur malam lebih larut. Hal tersebut berakibat pada kurangnya durasi tidur malam, dan terbangun lebih siang di pagi hari. Pada penelitian ini didapatkan hubungan bermakna antara jumlah waktu tidur siang dengan kriteria gangguan tidur (MannWhitney $U, p=0,001$ ).

Pada penelitian ini rata-rata lama waktu yang dibutuhkan untuk anak jatuh tertidur pada malam hari 28,6 menit. Hal yang sama dijumpai pada penelitian Avi Sadeh, lama waktu yang dibutuhkan untuk jatuh tertidur pada malam hari pada anak dengan gangguan tidur $(28,8 \pm 18,6)$ menit dan pada kelompok kontrol $(22,8 \pm 19,8)$ menit. ${ }^{13}$ Pada umumnya anak di atas 6 bulan memerlukan waktu 10-20 menit untuk jatuh tertidur. ${ }^{10}$ Hasil uji statistik tidak didapatkan hubungan bermakna antara lama jatuh tertidur pada malam hari dengan gangguan tidur (Mann-Whitney $U, p=0,361$ ).

Tabel 2. Sebaran anak berdasarkan cara tertidur

\begin{tabular}{lccc}
\hline Cara anak tertidur & & Frekuensi & Presentase \\
\hline Tertidur ketika disusui & Ya & 216 & 56.1 \\
& Tidak & 169 & 43.9 \\
Tertidur sendiri di tempat tidur & Ya & 87 & 22.6 \\
& Tidak & 298 & 77.4 \\
Tertidur ketika diayun & Ya & 77 & 20 \\
& Tidak & 308 & 80 \\
Tertidur di dekat orang tua & Ya & 89 & 23.1 \\
& Tidak & 296 & 76.9 \\
Tertidur di gendongan & Ya & 87 & 22.6 \\
& Tidak & 298 & 77.4 \\
\hline
\end{tabular}

Tabel 3. Hubungan antara cara tertidur dengan gangguan tidur

\begin{tabular}{|c|c|c|c|c|c|}
\hline \multicolumn{2}{|l|}{ Cara tertidur } & \multirow{2}{*}{$\begin{array}{c}\begin{array}{c}\text { Gangguan } \\
\text { Tidur }\end{array} \\
109\end{array}$} & \multirow{2}{*}{$\begin{array}{c}\text { Tidur } \\
\text { normal }\end{array}$} & \multirow[t]{2}{*}{ Uji kemaknaan* } & \multirow{2}{*}{$\begin{array}{l}\text { Kemaknaan } \\
\text { Bermakna }\end{array}$} \\
\hline Tertidur ketika disusui & ya & & & & \\
\hline & tidak & 61 & 108 & $\mathrm{p}=0,003$ & \\
\hline \multirow[t]{2}{*}{ Tertidur sendiri di tempat tidur } & ya & 30 & 57 & & \multirow[t]{2}{*}{ Tidak bermakna } \\
\hline & tidak & 140 & 158 & $\mathrm{p}=0,025$ & \\
\hline \multirow[t]{2}{*}{ Tertidur ketika diayun } & ya & 38 & 39 & & \multirow[t]{2}{*}{ Tidak bermakna } \\
\hline & tidak & 132 & 176 & $\mathrm{p}=0.184$ & \\
\hline \multirow[t]{2}{*}{ Tertidur di dekat Orangtua } & ya & 36 & 53 & & \multirow[t]{2}{*}{ Tidak bermakna } \\
\hline & tidak & 134 & 162 & $\mathrm{p}=0,46$ & \\
\hline \multirow[t]{2}{*}{ Tertidur di gendongan } & ya & 42 & 45 & & \multirow[t]{2}{*}{ Tidak bermakna } \\
\hline & tidak & 128 & 170 & $\mathrm{p}=0,39$ & \\
\hline
\end{tabular}

* Fisher's Exact test 
Pola tidur anak dibentuk dalam keluarga, faktor orangtua sangat berperan penting pada terbentuknya pola tidur yang baik untuk anak. Dua hal penting yang berkaitan dengan pola tidur adalah faktor lingkungan dalam rumah atau kamar tidur dan faktor internal dari anaknya sendiri. Faktor-faktor sosiodemografi seperti tingkat pendidikan orang tua, pekerjaan, tingkat pendapatan, jumlah anak merupakan faktor-faktor yang berkontribusi dalam gangguan tidur pada anak. Pada uji statistik tidak didapatkan hubungan bermakna antara tingkat pendidikan ayah, tingkat pendidikan ibu, tingkat pendapatan dan jumlah anak dengan gangguan tidur pada anak. Sebagian besar anak 25,2\% tidur pada jam 20.00 (jam 8 malam). Waktu mulai tidur berkaitan erat dengan lama anak tertidur pada malam hari. Hasil uji statistik didapatkan hubungan bermakna antara waktu mulai tidur dengan gangguan tidur (Chi-Square, $p=0,006$ ). Lama tidur malam ratarata 9,4 jam dan lama tidur siang 3,4 jam. Setiap anak mempunyai kebutuhan tidur yang berbeda, tergantung usia anak. Pada awal kehidupan perbandingan jumlah tidur malam dan siang hampir sama. Semakin bertambah umur anak prosentase jumlah tidur pada siang hari lebih kecil dibandingkan jumlah jam tidur pada malam hari.

Sebagian besar orangtua $(42,3 \%)$ menganggap bahwa gangguan tidur pada anak bukan merupakan suatu masalah, 29,9\% menggangap masalah yang kecil dan $27,8 \%$ merupakan masalah yang sangat serius. Tetapi secara statistik tidak ada hubungan bermakna antara anggapan ibu tentang gangguan tidur pada anak dengan gangguan tidur (Chi-Square, $p=0,074)$. Gangguan tidur seringkali dikeluhkan secara subjektif oleh orang tua tanpa memenuhi kriteria gangguan tidur. Banyak gangguan perilaku tidur adalah hasil interaksi antara perubahan pola tidur yang normal dan respons orangtua terhadap perubahan ini. ${ }^{9}$ Penting juga mengingat kebudayaan dan konteks keluarga ketika masalah tidur muncul. Sebagai contoh, co-sleeping antara bayi dan orangtua terdapat pada etnik tertentu seperti AfricanAmericans, Hispanics, dan Southeast Asia. Dengan demikian tujuan self soothing pada bayi tidak akan tercapai pada jenis keluarga seperti ini. ${ }^{12,16}$ Masih kurangnya pengetahuan ibu tentang pentingnya tidur pada tumbuh kembang anak tercermin dari pendapat ibu tentang masalah tidur pada anak. Sedangkan gangguan tidur pada anak dapat memberikan dampak baik pada aspek pertumbuhan fisik, maupun perkembangan kognitif, emosi, sosial dan perilaku anak. Salah satu cara adalah melakukan deteksi dini gangguan tidur menggunakan kuesioner BISQ. Selain itu edukasi kepada orangtua perlu digalakkan bahwa tidur adalah salah satu kebutuhan dasar anak untuk tumbuh kembang optimal.

Sebagai kesimpulan, prevalensi gangguan tidur pada anak dibawah 3 tahun ditemukan pada 44,2\% kasus yang diteliti dengan rata-rata usia anak 12 bulan. Ditemukan hubungan bermakna antara tertidur ketikaa disusui dan jumlah waktu tidur siang serta waktu mulai tidur malam dengan gangguan tidur. Tidak ditemukan hubungan bermakna antara faktor sosiodemografi dan gangguan tidur. Perangkat BISQ dapat merupakan salah satu alat untuk skrining gangguan tidur pada anak. Prevalensi gangguan tidur yang tinggi dan perhatian orangtua yang kurang terhadap masalah ini, perlu dilakukan penyebaran informasi dan penyuluhan kepada orang tua tentang manfaat tidur dan dampak yang ditimbulkan dari gangguan tidur.

\section{Daftar Pustaka}

1. Goodlin-Jones BL, Burnham MM, Gaylor EE, Anders TF. Night waking, sleep-wakr organization, and selfsoothing in the first year of life. Dev Behav Pediatr 2001; 22:226-33.

2. Salzarulo P, Chevaliet A. Sleep problems in children and their relationship with early distuebances of the waking-sleeping rhythms. Sleep 1983; 6:47-51.

3. Gaylor EE, Goodlin-Jones BL, Anders TF. Classification of yaoung children's sleep problems: A pilot study. J Am Acad Child Adolesc Psy 2001; 40:61-7.

4. Ramchandani P, Wiggs L, webb V, Stores G. Asystematic review of treatment for settling problems and night waking in young children. British Medical Journal 2000; 320:209-13.

5. Mindell JA. Empirically supported treatments in pediatric psychology: Bedtime refusal and night wakings in young children. J Pediatr Psychol 1999; 24:465-81

6. Glaze DG, Rosen CL, Owens JA. Toward a practical definition of pediatric insomnia. Current Therapeutic Research 2002; 63(suppl B):B4-17.

7. Pollock JL. Night waking at five years of age: Predictors and prognosis. Journal of Child Psychology and Child Psychiatry and allied Disciplines 1994: 35:699-708 
8. Canadian Pediatric Society. Creating a safe environment for your baby. 2004 November. Didapat dari: URL:http:/ lwww.caringfor kids.cps.calbabies/safesleep.htm

9. Owens JA. Sleep disorders. In Behrman RE, Kliegman RM, Jenson HB. Nelson Textbook of Pediatrics $17^{\text {th }} \mathrm{ed}$. United States of America: Saunders; 2004:75-8.

10. Thiedke CC. Sleep disorders and sleep problems in childhood. American Family Physician 2001 January. Didapat dari: URL: http://www.aafp.org/afp/200010115/277.html

11. Harris JC. Sleep disorders. In Oski’s Pediatrics: Principles and Practice $3^{\text {rd }}$ ed. United States of America: JB Lippincott Company 1999:822-7

12. Mindell JA, Owens JA. A Clinical Guide to Pediatrics Sleep : Diagnosis and management of sleep problems. United States of America: JB Lipincott Company 2003. h. 22-41

13. Sadeh A. A Brief screening questionnaires for infant sleep problems: validations and findings for an internet sample. Pediatrics 2004; 113:570-6.

14. Ghazali MV, Sastromihardjo S, Soedjarwo SR, Soelaryo T, Pramulyo H. Studi cross-sectional. Dalam: Sastroasmoro S, Ismael S. Dasar-dasar metodologi penelitian klinik. Edisi ke-2. Jakarta: CV Sagung seto, 2002; 97-108.

15. Tandradynata J, Mayasari KP, hapsari L, Ilmiawam L. Gangguan tidur dan faktor-faktor yang berhubungan pada anak usia bawah tiga tahun di wilayah binaan Yayasan Kampung KIDS November 2004. Laporan penelitian Kedokteran Komunitas terapan II. Jakarta, Fakultas Kedokteran UI, 2005.

16. Liu X, Liu L, Owens JA, Kaplan DL. Sleep patterns and sleep problems among schoolchildren in the United States and China. Pediatrics 2005; 115:241-9.

17. Jenni OG, Fuhrer HZ, Iglowstein I, Molinari L, Largo RH. A longitudinal study of bed sharing and sleep problems among Swiss children in the first 10 years of life. Pediatrics 2005; 115:233-40. 